\title{
PENGARUH INDEPENDENSI, AKUNTABILITAS, DAN OBJEKTIVITAS TERHADAP KUALITAS AUDIT
}

\author{
Arin Dea Laksita \\ Program Studi Akuntansi Fakultas Ekonomi Universitas Negeri Yogyakarta \\ arinlaksita@gmail.com \\ Sukirno \\ Staf pengajar Jurusan Pendidikan Akuntansi Universitas Negeri Yogyakarta \\ sukirno@uny.ac.id
}

\begin{abstract}
Abstrak : Pengaruh Independensi, Akuntabilitas, Dan Objektivitas Terhadap Kualitas Audit. Penelitian ini bertujuan untuk mengetahui: (1) pengaruh Independensi terhadap Kualitas Audit, (2) pengaruh Akuntabilitas terhadap Kualitas Audit, (3) pengaruh Objektivitas terhadap Kualitas Audit pada, (4) pengaruh Independensi, Akuntabilitas dan Objektivitas terhadap Kualitas Audit. Responden dalam penelitian ini adalah 41 auditor internal yang bekerja pada Inspektorat Provinsi Daerah Istimewa Yogyakarta. Teknik analisis data yang digunakan adalah analisis regresi linear sederhana, regresi linear berganda. Hasil penelitian ini menunjukkan bahwa (1) Terdapat pengaruh positif Independensi terhadap Kualitas Audit, (2) Terdapat pengaruh positif Akuntabilitas terhadap Kualitas Audit, (3) Terdapat pengaruh positif Objektivitas terhadap Kualitas Audit, (4) Terdapat pengaruh positif Independensi, Akuntabilitas, dan Objektivitas terhadap Kualitas Audit.
\end{abstract}

Kata kunci: Independensi, Akuntabilitas, Objektivitas, Kualitas Audit.

Abstract: The Effect Independence, Accountability, And Objectivity On Audit Quality. This research is conducted to examine : (1) The effect of Independence on Audit Quality, (2) The effect of Accountability on Audit Quality, (3) The effect of Objectivity on Audit Quality, (4) The effect of Independence, Accountability, and Objektivity on Audit Quality. Respondents in this research included 41 internal auditors work at inspectorate of Special Region of Yogyakarta. Data analysis technique used a simple linier regression and multiple linier regression. The results of the research showed that: (1) There was a positive effects Independence on Audit Quality, (2) There was a positive effects Accountability on Audit Quality, (3) There was a positive effects The effect of Objectivity on Audit Quality, (4) There was a positive effects The effect of Independence, Accountability, and Objektivity on Audit Quality.

Keyword : Independence, Accountability, Objectivity, Audit Quality.

\section{PENDAHULUAN}

Auditor merupakan pihak yang berperan penting dalam pengontrol dan pengawas di bidang keuangan, untuk memberikan informasi yang akurat dan dapat dipercaya dalam pengambilan keputusan. Auditor bertanggung jawab untuk merencanakan dan melaksanakan audit untuk memperoleh keyakinan memadai tentang apakah laporan keuangan bebas dari salah saji material baik yang disebabkan oleh kekeliruan atau kecurangan.

Tuntutan pelaksanaan akuntabilitas sektor publik terhadap terwujudnya good governance di Indonesia semakin meningkat. Hal ini berhubungan dengan krisis ekonomi yang terjadi di Indonesia semakin meningkat. Hal ini berhubungan dengan krisis ekonomi yang terjadi di Indonesia. Krisis ekonomi tersebut disebabkan oleh buruknya pengelolaan dan 


\section{JURNAL NOMINAL / VOLUMEN VIII NOMOR 1 / TAHUN 2019}

buruknya birokrasi yang disebabkan oleh merajalelanya korupsi. Banyaknya kasus korupsi, kolusi, dan nepotisme (KKN) di Indonesia dalam beberapa tahun terakhir menjadi perhatian masyarakat. Banyak pejabat yang melakukan kasus $\mathrm{KKN}$, seperti penyelewengan wewenang, pungutan liar,uang pelicin, uang suap atau uang tutup mulut, sampai menggunakan uang negara.

Menurut Mardiasmo (2005), terdapat tiga aspek utama yang mendukung terciptanya kepemerintahan yang baik (good governance), yaitu pengawasan, pengendalian, dan pemeriksaan. Pengawasan merupakan kegiatan yang dilakukan oleh pihak di luar eksekutif, yaitu masyarakat dan Dewan Perwakilan Rakyat Daerah (DPRD) untuk mengawasi kinerja pemerintahan. Pengendalian (control) adalah suatu cara yang dilakukan oleh eksekutif untuk menjamin bahwa sistem dan kebijakan manajemen dilaksanakan dengan baik sehingga tujuan organisasi dapat tercapai. Sedangkan pemeriksaan (audit) merupakan kegiatan yang dilakukan oleh pihak independen untuk memeriksa apakah hasil kinerja pemerintah telah sesuai dengan standar yang ditetapkan.

Auditor atau akuntan dapat dikelompokkan dalam tiga kategori yaitu akuntan publik, akuntan pemerintah dan akuntan internal. Akuntan publik atau bisa disebut Auditor Independen merupakan auditor yang melakukan fungsi pengauditan atas laporan keuangan yang diterbitkan oleh perusahaan. Auditor Eksternal Pemerintah yang dilaksanakan oleh Badan Pemeriksa Keuangan (BPK), Auditor Internal Pemerintah atau yang lebih dikenal sebagai Aparat Pengawasan Internal Pemerintah (APIP) yang dilaksanakan oleh Badan Pengawasan Keuangan dan Pembangunan (BPKP), Inspektorat Jenderal Kementerian, Inspektorat/unit pengawasan intern pada Kementerian Negara, Inspektorat Utama/Inspektorat Lembaga Pemerintah Non Kementerian, Inspektorat/unit pengawasan intern pada Kesekretariatan Lembaga Tinggi Negara dan Lembaga Negara ,Inspektorat Provinsi/Kabupaten/Kota, dan unit pengawasan intern pada Badan Hukum Pemerintah lainnya sesuai dengan peraturan perundang-undangan.

Menurut Musa Yosep (2016), fungsi audit internal memberikan penilaian independen tentang kecukupan kebijakan dan prosedur kepatuhan. Audit internal membantu manajemen senior dan dewan direksi dalam melaksanakan tanggung jawab secara efektif dan efisien. Auditor internal berpengaruh penting dalam proses terciptanya akuntabilitas dan transparansi pengelolaan keuangan daerah, karena dalam laporan keuangan suatu daerah 


\section{JURNAL NOMINAL / VOLUMEN VIII NOMOR 1 / TAHUN 2019}

sangat perlu adanya transparansi laporan keuangan guna untuk mengetahui alokasi dana pemerintah. Salah satu unit yang melakukan audit/pemeriksaan terhadap pemerintah daerah adalah inspektorat daerah. Peran dan fungsi Inspektorat Provinsi, Kabupaten/Kota secara umum diatur dalam pasal 4 Peraturan Menteri Dalam Negeri No. 64 Tahun 2007 tentang Pedoman Teknis Organisasi dan Tata Kerja Inspektorat Provinsi dan Kabupaten/Kota. Dalam pasal tersebut dinyatakan bahwa dalam melaksanakan tugas pengawasan urusan pemerintahan, Inspektorat Provinsi, Kabupaten/Kota mempunyai fungsi sebagai berikut: pertama, perencanaan program pengawasan; kedua, perumusan kebijakan dan fasilitas pengawasan; dan ketiga, pemeriksaan, pengusutan, pengujian, dan penilaian tugas pengawasan.

Dengan besarnya dana yang dimiliki oleh pemerintah untuk pengelolaan suatu negara, maka diperlukan pengawasan yang cukup andal dalam pertanggungjawaban atas penggunaan dana tersebut. Pengawasan yang cukup andal diharapkan dapat menjamin pendistribusian dana yang merata, sehingga efektivitas dan efisien penggunaan dana dapat dipertanggungjawabkan. Terkait dengan proses pengawasan dan pemeriksaan atas pengelolaan keuangan pemerintah, diperlukan audit sektor publik yang berkualitas.

Laporan keuangan yang telah diaudit kewajarannya lebih dapat dipercaya dibandingkan laporan keuangan yang tidak atau belum diaudit, oleh karena itu diperlukan suatu jasa profesional yang independen dan objektif untuk menilai kewajaran laporan keuangan yang disajikan oleh manajemen atau auditee. Berkualitas atau tidaknya suatu laporan keuangan dapat dilihat dari karakteristik laporan keuangan tersebut. Menurut FASB, dua karakteristik terpenting yang harus ada dalam laporan keuangan adalah relevan (relevance) dan dapat diandalkan (reliable). Auditor harus memiliki kualitas audit yang tinggi agar hasil audit laporan keuangan dapat dipercaya oleh pihak yang berkepentingan.

Audit pemerintahan merupakan salah satu elemen penting dalam penegakan good governance. Dalam rangka mewujudkan good governance pemerintah harus melakukan perubahan pada seluruh sektor pemerintahan khususnya bidang pengelolaan keuangan daerah. Perubahan yang harus dilakukan dalam pengelolaan keuangan daerah yaitu adanya audit internal maupun eksternal terhadap seluruh kegiatan yang diselenggarakan oleh pemerintah. Dengan adanya perubahan tersebut, maka diharapkan kegiatan yang dilaksanakan berjalan dengan maksimal, sehingga 


\section{JURNAL NOMINAL / VOLUMEN VIII NOMOR 1 / TAHUN 2019}

kesalahan dan tindak pidana yang dapat merugikan negara bisa berkurang.

Adanya perubahan yang baik dalam bidang pengawasan pengelolaan keuangan daerah, maka kualitas audit akan meningkat. Auditor akan memberikan keyakinan positif yang dibuat manajemen dalam laporan keuangan apabila menunjukkan tingkat keyakinan kepastian bahwa laporannya adalah benar. Tingkat keyakinan yang mampu dicapai auditor akan ditentukan oleh hasil bukti yang dikumpulkan. Semakin banyak jumlah bukti yang relevan dan kompeten, semakin tinggi pula keyakinan yang dicapai oleh auditor.

Akuntabilitas merupakan salah satu faktor yang mempengaruhi kualitas audit. Menurut Hafizh (2007) menjelaskan akuntabilitas adalah bentuk dorongan psikis yang membuat seseorang bertanggung jawab atas semua tindakan dan keputusan yang diambilnya. Pemerintah pusat dan pemerintah daerah bertindak sebagai pelaku pemberi informasi untuk memenuhi hakhak publik, yaitu hak untuk tahu, hak untuk diberi informasi, dan hak untuk didengar informasinya. Berdasarkan penelitian yang dilakukan oleh Dayanara (2016) akuntabilitas berpengaruh positif dan signifikan terhadap kualitas audit, maka semakin tinggi akuntabilitias auditor semakin baik pula kualitas audit yang dihasilkan.

Sikap independensi juga harus dimiliki oleh auditor. Independensi menjadi sikap yang harus dijunjung tinggi, agar dapat menjaga kepercayaan yang diberikan oleh masyarakat. Sikap inilah yang mampu menjaga auditor agar tidak terpengaruh terhadap segala sesuatu yang dapat mempengaruhi kualitas audit yang dihasilkan. Terkait dengan Independensi, auditor internal pemerintah memiliki posisi yang rentan terhadap tekanan politik. Kadang intervensi politik bisa terjadi jika temuan terkait sampai dengan ranah politik. Auditor internal akan berada di bawah pengaruh pihak penentu kebijakan. Bersikap independen berarti menghindarkan hubungan yang dapat menggangu sikap mental dan penampilan objektif auditor dalam melaksanakan audit. Klien mereka adalah manajemen senior, dewan komisaris, atau badan-badan sejenis, sehingga jika auditor diminta untuk melanggar kode etik atau standar praktik profesional, maka bisa menyebabkan auditor kehilangan pekerjaan mereka apabila tidak memiliki independensi. Penelitian yang dilakukan oleh Indah (2010), Elfarini (2007), dan Septiana (2013) yang memberi bukti empiris bahwa independensi berpengaruh positif terhadap 


\section{JURNAL NOMINAL / VOLUMEN VIII NOMOR 1 / TAHUN 2019}

kualitas audit. Independensi yang tinggi akan memiliki pengaruh terhadap hasil pekerjaan. Seorang auditor yang independen tidak akan terpengaruh pada intervensi dari pihak luar ketika melakukan pekerjaannya. Kondisi ini berhubungan dengan kualitas audit yang akan dihasilkan. Hal ini berarti bahwa semakin tinggi independensi auditor semakin tinggi kualitas audit. Selain beberapa faktor diatas, objektivitas juga berpengaruh terhadap kualitas audit. Dalam pasal 1 ayat 2 Kode Etik Akuntan Indonesia menyebutkan bahwa setiap anggota harus mempertahankan integritas dan objektivitas dalam melaksanakan tugasnya. Dengan mempertahankan integritas, ia akan bertindak jujur, tegas, dan tanpa pretensi. Dengan mempertahankan objektivitas, ia akan bertindak adil tanpa dipengaruhi tekanan atau permintaan pihak tertentu atau kepentingan pribadinya. Objektivitas diperlukan agar auditor dapat bertindak adil tanpa dipengaruhi oleh tekanan atau permintaan pihak tertentu yang berkepentingan atas hasil audit. Semakin tinggi tingkat objektivitas auditor maka semakin baik kualitas audit. Dengan kata lain, semakin tinggi tingkat objektivitas auditor maka semakin baik kualitas audit atau kinerjanya. Demikian sebaliknya bila objektivitas rendah/buruk maka kinerja auditor akan buruk/rendah.
Menurut Sukriah, dkk (2009) menyatakan bahwa masalah sulit yang dihadapi oleh seorang auditor untuk meningkatkan Kualitas Audit adalah bagaimana meningkatkan sikap dan perilaku aparat pengawasan dalam melaksanakan pemeriksaan, sehingga pengawasan yang dilakukan berjalan dengan wajar, efektif, dan efisien. Namun pada kenyataannya Kualitas Audit masih menjadi sorotan, karena masih banyak ditemukannya temuan audit yang tidak terdeteksi oleh aparat inspektorat sebagai auditor internal, akan tetapi ditemukan oleh auditor eksternal yaitu Badan Pemeriksa Keuangan (BPK).

Peneliti memilih Inspektorat Provinsi Provinsi Daerah Istimewa Yogyakarta sebagai objek penelitian karena Inspektorat dipandang sebagai pengawas intern pemerintahan dimana penting bagi sebuah organisasi untuk memperkuat pengawasan intern terlebih dahulu untuk menghasilkan kinerja yang maksimal. Inspektorat Provinsi Daerah Istimewa Yogyakarta juga lebih luas jangkauannya daripada Inspektorat Kabupaten/Kota sehingga permasalahan yang ada pun lebih kompleks.

Dalam penelitian ini, peneliti menggunakan kombinasi variabel-variabel independen penelitian yang dilakukan oleh peneliti sebelumnya untuk dianalisis 


\section{JURNAL NOMINAL / VOLUMEN VIII NOMOR 1 / TAHUN 2019}

pengaruhnya terhadap peningkatkan kualitas audit yang dilakukan pada auditor internal pemerintah. Penelitian ini dilakukan untuk mengetahui faktor-faktor yang mempengaruhi audit yaitu Independensi, Akuntabilitas, dan Objektivitas. Apabila auditor mempunyai prinsip perilaku tersebut maka akan meningkatkan kualitas audit yang dihasilkan. penelitian ini untuk menilai sejauh mana auditor dapat konsisten dalam menjaga kualitas hasil audit.

Berdasarkan dasar latar belakang di atas, peneliti mengangkat judul "Pengaruh Independensi, Akuntabilitas, dan Objektivitas tehadap Kualitas Audit" (Studi Empiris pada Auditor Internal Inspektorat Provinsi Daerah Istimewa Yogyakarta).

\section{METODE PENELITIAN}

\section{Jenis Penelitian}

Penelitian ini menggunakan jenis peneletian asosiatif adalah penelitian yang bertujuan untuk mengetahui hubungan antara dua variabel atau lebih (Sugiyono, 2012).

\section{Waktu dan Tempat Penelitian}

Penelitian ini dilakukan di Inspektorat Provinsi Daerah Istimewa Yogyakarta pada Inspektorat Provinsi DIY. Waktu pelaksanaannya pada bulan Desember-Mei 2018 .

\section{Populasi Penelitian}

Penelitian ini mengambil populasi auditor internal yang bekerja di Inspektorat Provinsi Daerah Istimewa Yogyakarta yang berjumlah 41 orang. Penelitian ini menggunakan uji coba terpakai, yaitu uji coba instrumen penelitian ini diambil dari dalam populasi dengan 41 responden, yang kemudian hasilnya akan langsung digunakan untuk penelitian.

\section{Prosedur}

Teknik pengumpulan data dalam penelitian ini adalah dengan menggunakan metode kuesioner dan metode wawancara. Dalam penelitian ini, responden akan mengumpulkan data menggunakan kuesioner yang telah dibagikan dengan skala likert yang digunakan dengan rentang 1 sampai 4. Kuesioner ini akan digunakan untuk mengukur Independensi, Akuntabilitas, dan Objektivitas terhadap Kualitas Audit pada auditor internal di Inspektorat Provinsi Daerah Istimewa Yogyakarta.

Sebelum dilakukan uji hipotesis, penelitian ini mendistribusikan 41 kuesioner pada instansi untuk dilakukan uji validitas dan reliabilitas. Kuesioner yang kembali adalah 38 kuesioner. Tingkat pengembalian kuesioner sebesar 92,68\%. Sehingga penelitian ini menggunakan 38 kuesioner tersebut untuk uji selanjutnya. 


\section{Teknik Analisis Data}

Untuk uji hipotesis menggunakan yaitu 1) Analisis regresi linear sederhana digunakan untuk menguji hipotesis pertama, kedua dan ketiga. Untuk mencari dengan menggunakan persamaan regresi, mencari koefisien korelasi (R), mencari koefisien determinasi (R Square), dan uji t diperlukan untuk menguji signifikansi dan setiap variabel independen akan berpengaruh terhadap variabel dependen. 2) Analisis regresi berganda dilakukan untuk menguji pengaruh simultan dari Independensi, Akuntabilitas, dan Objektivitas terhadap Kualitas Audit. Analisis regresi linear berganda dalam penelitian ini digunakan untuk menguji hipotesis empat. Untuk mencari dengan menggunakan persamaan regresi, mencari koefisien korelasi (R), mencari koefisien determinasi (R Square), dan uji F untuk mencari signifikansi koefisien korelasi secara simultan.

\section{HASIL PENELITIAN DAN}

\section{PEMBAHASAN}

\section{Hasil Penelitian}

Analisis deskripsi data yang disajikan dalam penelitian ini meliputi Minimum, Maksimum, Mean (M), dan Standar Deviasi (SD).

\begin{tabular}{cccccc}
\hline $\begin{array}{c}\text { Varia } \\
\text { bel }\end{array}$ & $\mathbf{N}$ & Min & Max & M & SD \\
\hline $\mathbf{X}_{\mathbf{1}}$ & 38 & 13 & 52 & $\begin{array}{c}32,50 \\
0\end{array}$ & $\begin{array}{c}6,50 \\
0\end{array}$ \\
\hline $\mathbf{X}_{\mathbf{2}}$ & 38 & 6 & 24 & 15 & 3 \\
\hline $\mathbf{X}_{\mathbf{3}}$ & 38 & 7 & 28 & $\begin{array}{c}17,50 \\
0\end{array}$ & $\begin{array}{c}3,50 \\
0\end{array}$ \\
\hline $\mathbf{Y}$ & 38 & 7 & 28 & $\begin{array}{c}17,50 \\
0\end{array}$ & $\begin{array}{c}3,50 \\
0\end{array}$ \\
& & & & 0
\end{tabular}

Tabel 1. Hasil Deskripsi Statistik Variabel (Sumber: Data Primer yang Diolah)

Variabel $\mathrm{X}_{1}$ adalah Independensi dengan skor tertinggi 24, sedangkan skor terendah 6. Mean 15, dan Standar Deviasi 6,500. Variabel $\mathrm{X}_{2}$ adalah Akuntabilitas dengan skor tertinggi 28, skor terendah 7 . Mean 17,500, dan Standar Deviasi 3,500. Variabel $\mathrm{X}_{3}$ adalah Objektivitas dengan skor tertinggi 28, skor terendah 7. Mean 17,500, dan Standar Deviasi 3,500. Kemudian, untuk Y adalah Kualitas Audit dengan skor tertinggi 54, skor terendah 13. Mean 32,500, dan Standar Deviasi 6,500.

Berikut adalah hasil uji hipotesis: 1) Analisis regresi sederhana ini digunakan untuk mengetahui hubungan variabel independen secara parsial terhadap variabel dependen. Analisis regresi sederhana ini digunakan untuk hipotesis pertama hingga ketiga. 


\begin{tabular}{ccccccc}
\hline Var & Kons & $\begin{array}{c}\text { Koef } \\
\text { Reg }\end{array}$ & $\mathbf{R}$ & $\mathbf{R}^{\mathbf{2}}$ & thitun & Sig \\
& \multicolumn{7}{c}{$\mathbf{X}_{\mathbf{1}}$} & 28,31 & 0,635 & 0,58 & 0,33 & 10,9 & 0,00 \\
$\mathbf{Y}$ & 1 & & 0 & 6 & 29 & 0 \\
& & & & & & \\
\hline $\mathbf{X}_{2-}$ & 13, & 1, & 0,51 & 0,26 & 3,55 & 0,00 \\
$\mathbf{Y}$ & 281 & 972 & 0 & 0 & 8 & 1 \\
& & & & & & \\
\hline $\mathbf{X 3}_{3-}$ & 22,35 & 0,779 & 0,46 & 0,21 & 3,12 & 0,00 \\
$\mathbf{Y}$ & 6 & & 2 & 3 & 3 & 4
\end{tabular}

Tabel 2. Analisis Regresi H1, H2, H3 (Sumber : Data Primer yang Diolah)

H1 : Independensi berpengaruh positif terhadap Kualitas Audit pada Inspektorat Provinsi Daerah Istimewa Yogyakarta.

Berdasarkan tabel tersebut maka dapat disusun persamaan regresinya yaitu :

$$
\mathrm{Y}=28,311+0,635 \mathrm{X}_{1}
$$

Berdasarkan persamaan regresi tersebut, maka dapat dilihat bahwa konstanta sebesar 28,311. Hal tersebut menunjukkan bahwa jika variabel Kualitas Audit pada Inspektorat Provinsi DIY dianggap nol, maka perubahan Independensi adalah sebesar 28,311. Sedangkan koefisien regresi Independensi sebesar 0,635 menyatakan bahwa setiap kenaikan Independensi sebesar 1 satuan akan meningkatkan Kualitas Audit pada Inspektorat Provinsi Daerah Istimewa Yogyakarta sebesar 0,635 satuan. Hal ini berarti arah model tersebut adalah positif. Hal ini dapat dilihat nilai koefisien $\mathrm{R}$ yang bernilai positif antara Independensi dan
Kualitas Audit sebesar 0,580. Selain itu, nilai $R$ Square sebesar 0,336 menunjukkan bahwa 33,6\% Kualitas Audit pada Inspektorat Provinsi DIY dipengaruhi oleh Independensi, sedangkan sisanya sebesar $66,4 \%$ dipengaruhi oleh variabel lain.

Dengan $t$ hitung sebesar 10,929 yang nilainya lebih besar dari t tabel yaitu 2,021. Kemudian untuk uji t statistik untuk variabel Independensi menghasilkan nilai signifikan 0,000 dan lebih kecil dari 0,050. Maka dari itu dapat disimpulkan bahwa Independensi berpengaruh positif terhadap Kualitasi Audit pada Inspektorat Provinsi Daerah Istimewa Yogyakarta sehingga semakin tinggi Independensi maka akan semakin tinggi pula Kualitas Audit. Maka dapat disimpulkan bahwa hipotesis pertama yang menyatakan bahwa adanya pengaruh positif Independensi terhadap Kualitasi Audit pada Inspektorat Provinsi Daerah Istimewa Yogyakarta diterima.

\section{H2 : Independensi berpengaruh positif terhadap Kualitas Audit pada Inspektorat Provinsi Daerah Istimewa Yogyakarta.}

Berdasarkan tabel tersebut maka dapat disusun persamaan regresinya yaitu :

$$
\mathrm{Y}=13,281+1,072 \mathrm{X}_{2}
$$

Berdasarkan persamaan regresi tersebut, maka dapat dilihat bahwa konstanta sebesar 13,281. Hal tersebut menunjukkan bahwa jika variabel Kualitas 


\section{JURNAL NOMINAL / VOLUMEN VIII NOMOR 1 / TAHUN 2019}

Audit pada Inspektorat Provinsi DIY dianggap nol, maka perubahan Akuntabilitas adalah sebesar 13,281. Sedangkan koefisien regresi Akuntabilitas sebesar 1,072 menyatakan bahwa setiap kenaikan Akuntabilitas sebesar 1 satuan akan meningkatkan Kualitas Audit pada Inspektorat Provinsi Daerah Istimewa Yogyakarta sebesar 1,072 satuan. Hal ini berarti arah model tersebut adalah positif. Hal ini dapat dilihat nilai koefisien $\mathrm{R}$ yang bernilai positif antara Akuntabilitas dan Kualitas Audit sebesar 0,510. Selain itu, nilai $R$ Square sebesar 0,260 menunjukkan bahwa 26\% Kualitas Audit pada Inspektorat Provinsi DIY dipengaruhi oleh Akuntabilitas, sedangkan sisanya sebesar $74 \%$ dipengaruhi oleh variabel lain.

Dengan t hitung sebesar 3,558 yang nilainya lebih besar dari t tabel yaitu 2,021. Kemudian untuk uji $\mathrm{t}$ statistik untuk variabel Akuntabilitas menghasilkan nilai signifikan 0,001 dan lebih kecil dari 0,050. Maka dari itu dapat disimpulkan bahwa Independensi berpengaruh positif terhadap Kualitasi Audit pada Inspektorat Provinsi Daerah Istimewa Yogyakarta sehingga semakin tinggi Independensi maka akan semakin tinggi pula Kualitas Audit. Maka dapat disimpulkan bahwa hipotesis pertama yang menyatakan bahwa adanya pengaruh positif Independensi terhadap Kualitasi
Audit pada Inspektorat Provinsi Daerah Istimewa Yogyakarta diterima.

\section{H3 : Objektivitas berpengaruh positif terhadap Kualitas Audit pada Inspektorat Provinsi Daerah Istimewa Yogyakarta.}

Berdasarkan tabel tersebut maka dapat disusun persamaan regresinya yaitu :

$$
\mathrm{Y}=22,356+0,779 \mathrm{X}_{3}
$$

Berdasarkan persamaan regresi tersebut, maka dapat dilihat bahwa konstanta sebesar 22,356. Hal tersebut menunjukkan bahwa jika variabel Kualitas Audit pada Inspektorat Provinsi DIY dianggap nol, maka perubahan Objektivitas adalah sebesar 22,356. Sedangkan koefisien regresi Objektivitas sebesar 0,779 menyatakan bahwa setiap kenaikan Objektivitas sebesar 1 satuan akan meningkatkan Kualitas Audit pada Inspektorat Provinsi Daerah Istimewa Yogyakarta sebesar 0,779 satuan. Hal ini berarti arah model tersebut adalah positif. Hal ini dapat dilihat nilai koefisien $\mathrm{R}$ yang bernilai positif antara Objektivitas dan Kualitas Audit sebesar 0,462. Selain itu, nilai $R$ Square sebesar 0,462 menunjukkan bahwa 46,2\% Kualitas Audit pada Inspektorat Provinsi DIY dipengaruhi oleh Objektivitas, sedangkan sisanya sebesar $66,4 \%$ dipengaruhi oleh variabel lain.

Dengan thitung sebesar 4,112 yang nilainya lebih besar dari t tabel yaitu 2,021. 


\section{JURNAL NOMINAL / VOLUMEN VIII NOMOR 1 / TAHUN 2019}

Kemudian untuk uji $\mathrm{t}$ statistik untuk variabel Objektivitas menghasilkan nilai signifikan 0,004 dan lebih kecil dari 0,050. Maka dari itu dapat disimpulkan bahwa Objektivitas berpengaruh positif terhadap Kualitasi Audit pada Inspektorat Provinsi Daerah Istimewa Yogyakarta sehingga semakin tinggi Objektivitas maka akan semakin tinggi pula Kualitas Audit. Maka dapat disimpulkan bahwa hipotesis pertama yang menyatakan bahwa adanya pengaruh positif Objektivitas terhadap Kualitasi Audit pada Inspektorat Provinsi Daerah Istimewa Yogyakarta diterima.

2) Analisis regresi berganda dilakukan untuk menguji pengaruh simultan dari beberapa variabel bebas terhadap satu variabel terikat yang berskala interval.

H4 : Independensi, Akuntabilitas, dan Objektivitas secara simultan berpengaruh positif terhadap Kualitas Audit pada Inspektorat Daerah Istimewa Yogyakarta.

Berikut diperoleh hasil regresi linier berganda maka diperoleh tabel berikut:

\begin{tabular}{lc}
\hline Variabel & Koefisien Regresi \\
\hline Konstanta & 4,974 \\
\hline $\mathbf{X}_{\mathbf{1}}$ & 0,411 \\
\hline $\mathbf{X}_{\mathbf{2}}$ & 0,727 \\
\hline $\mathbf{X}_{\mathbf{3}}$ & 0,443 \\
\hline F hitung & 12,044 \\
\hline F table & 2,85 \\
\hline $\mathbf{R}$ & 0,718 \\
\hline Sig F & 0,000 \\
\hline R Square & 0,515 \\
\hline Tabel 3. An
\end{tabular}

Tabel 3. Analisis Regresi H4 (Sumber : Data Primer yang Diolah)
Persamaan garis regresi berdasarkan hasil analisis regresi linier berganda adalah sebagai berikut :

$\mathrm{Y}=4,974+0,411 \mathrm{X}_{1}+0,727 \mathrm{X}_{2}+0,443 \mathrm{X}_{3}$

Dari persamaan tersebut dapat disimpulkan bahwa nilai konstantanya adalah 4,974. $\mathrm{X}_{1}$ memiliki nilai koefisien sebesar 0,411 yang berarti jika Independensi meningkat sebesar 1 satuan maka Kualitas Audit akan meningkat sebesar 0,411 dengan asumsi $\mathrm{X}_{2}$ dan $\mathrm{X}_{3}$ tetap. Selanjutnya, $X_{2}$ memiliki nilai koefisien sebesar 0,727 yang berarti jika Akuntabilitas semakin efektif 1 satuan maka Kualitas Audit akan meningkat sebesar 0,727 satuan dengan asumsi $\mathrm{X}_{1}$ dan $\mathrm{X}_{3}$ tetap. Kemudian, untuk $\mathrm{X}_{3}$ memiliki nilai koefisien sebesar 0,443 yang berarti jika Objektivitas meningkat 1 satuan maka Kualitas Audit akan meningkat sebesar 0,443 satuan dengan asumsi $\mathrm{X}_{1}$ dan $\mathrm{X}_{2}$ tetap. Selain itu, dapat dilihat nilai korelasi regresi (R) yang bernilai positif sebesar 0,718. Maka dapat diartikan bahwa variabel-variabel tersebut memiliki hubungan yang positif dan searah.

Hasil perhitungan dalam tabel hasil analisis regresi linier berganda tersebut diperoleh $F_{\text {hitung }}$ sebesar 12,044 sedangkan $F_{\text {tabel }}$ sebesar 2,85. Selain itu, jika dilihat dari nilai probabilitas lebih kecil dari 0,050 yaitu nilai signifikansi $\mathrm{F}$ adalah $0,000<$ 0,050. Dengan demikian $F_{\text {hitung }}>F_{\text {tabel }}$ dan 
nilai probabilitas signifikansi $<0,050$ maka dapat diartikan bahwa Independensi, Akutabilitas, dan Objektivitas secara bersama-sama berpengaruh positif terhadap Kualitas Audit pada Inspektorat Daerah Istimewa Yogyakarta.

Dengan demikian dapat disimpulkan bahwa hipotesis keempat yang menyatakan bahwa adanya pengaruh positif Independensi, Akuntabilitas, dan Objektivitas terhadap Kualitas Audit pada Inspektorat Provinsi Daerah Istimewa Yogyakarta.

Berikut hasil sumbangan efektif dan sumbangan relatif sebagai berikut:

\begin{tabular}{cccc}
\hline No & $\begin{array}{c}\text { Variabe } \\
\mathbf{l}\end{array}$ & $\begin{array}{c}\text { Sumbanga } \\
\text { n Efektif } \\
(\boldsymbol{\%})\end{array}$ & $\begin{array}{c}\text { Sumbanga } \\
\text { n Relatif } \\
(\boldsymbol{\%})\end{array}$ \\
\hline $\mathbf{1}$ & $\mathrm{X}_{1}-\mathrm{Y}$ & $21,800 \%$ & $42,300 \%$ \\
\hline $\mathbf{2}$ & $\mathrm{X}_{2}-\mathrm{Y}$ & $17,600 \%$ & $34,200 \%$ \\
\hline $\mathbf{3}$ & $\mathrm{X}_{3}-\mathrm{Y}$ & $12,100 \%$ & $23,500 \%$ \\
\hline & Jumlah & $51,500 \%$ & $100 \%$ \\
\hline
\end{tabular}

Tabel 4. Rangkuman Hasil Sumbangan Efektif dan Relatif (Sumber : Data Primer yang Diolah)

Dari tabel tersebut diketahui bahwa memiliki sumbangan efektif dengan total $51,500 \%$ dengan variabel Independensi sebesar 21,800\%, variabel Akuntabilitas sebesar $17,600 \%$, dan variabel Objektivitas sebesar 12,100\%. Kemudian untuk sumbangan relatif diperoleh bahwa Independensi sebesar 42,300\%, variabel Akuntabilitas sebesar 34,200\%, dan variabel Objektivitas sebesar 23,500\%. Maka dapat disimpulkan bahwa dilihat dari sumbangan efektif dan sumbangan relatif dapat disimpulkan bahwa Independensi memiliki pengaruh yang lebih dominan terhadap Kualitas Audit pada Inspektorat Provinsi Daerah Istimewa Yogyakarta.

\section{Pembahasan}

a) Pengaruh Independensi terhadap Kualitas Audit pada Inspektorat Provinsi Daerah Istimewa Yogyakarta

Hasil ini mendukung hipotesis 1 yaitu terdapat pengaruh positif Independensi terhadap Kualitas Audit pada Inspektorat Provinsi Daerah Istimewa Yogyakarta. Hal ini dibuktikan dengan uji t yang dilakukan menunjukkan bahwa t hitung sebesar 10,929 lebih besar dari t tabel sebesar 2,021 dan nilai probabilitas signifikan 0,000 dan lebih kecil dari 0,050 sehingga dapat disimpulkan bahwa Independensi berpengaruh positif terhadap Kualitas Audit pada Inspektorat Provinsi Daerah Istimewa Yogyakarta.

Hasil penelitian ini sejalan dengan penelitian yang dilakukan oleh Listya Yuniastuti Rahmania dan Sukrisno Agoes (2014) yang berjudul Influence of auditor independence, audit tenure, and audit fee on audit quality of members of capital market accountant forum in 


\section{JURNAL NOMINAL / VOLUMEN VIII NOMOR 1 / TAHUN 2019}

Indonesia yang menyatakan bahwa Independensi berpengaruh positif signifikan terhadap Kualitas Audit. Penelitian ini menunjukkan bahwa semakin tinggi independensi auditor, maka akan semakin tinggi kualitas auditnya.

Penelitian ini memberikan informasi bahwa Independensi berpengaruh positif terhadap Kualitas Audit pada Auditor Internal di Inspektorat Provinsi Daerah Istimewa Yogyakarta. Hal ini berarti bahwa Independensi bisa membuat instansi mempertahankan hal-hal yang positif mengenai Kualitas Audit yang dihasilkan, karena adanya kejujuran dalam diri auditor dan tidak memihak dalam menyatakan pendapatnya.

b) Pengaruh Akuntabilitas terhadap Kualitas Audit pada Inspektorat Provinsi Daerah Istimewa Yogyakarta

Hasil ini mendukung hipotesis 2 yaitu terdapat pengaruh positif Akuntabilitas terhadap Kualitas Audit pada Inspektorat Provinsi Daerah Istimewa Yogyakarta. Hal ini dibuktikan dengan uji t yang dilakukan menunjukkan bahwa $t$ hitung sebesar 3,558 lebih besar dari t tabel sebesar 2,021 dan nilai probabilitas signifikan 0,001 dan lebih kecil dari 0,050 sehingga dapat disimpulkan bahwa Akuntabilitas berpengaruh positif terhadap Kualitas Audit pada Inspektorat Provinsi Daerah Istimewa Yogyakarta.

Hasil penelitian ini sejalan dengan penelitian yang dilakukan oleh Olivia Furiady dan Ratnawati Kurnia (2015) yang berjudul The effect of work experiences, competency, motivation, accountability and objektivity towards audit quality yang menyatakan bahwa akuntabilitas mempengaruhi kualitas audit. Hal ini karena akuntabilitas sangat penting bagi auditor sebagai faktor yang mempengaruhi kualitas audit. akuntabilitas menunjukkan bahwa auditor dapat menyelesaikan audit dengan baik dan tepat waktu, yakin bahwa pekerjaan ini diperiksa dengan teliti, ditinjau oleh pengawas, dan bertanggung jawab kepada pemberi kerja.

Penelitian ini memberikan informasi bahwa Akuntabilitas berpengaruh positif terhadap Kualitas Audit pada Auditor Internal di Inspektorat Provinsi Daerah Istimewa Yogyakarta. Hal ini berarti bahwa Akuntabilitas bisa membuat instansi mempertahankan hal-hal yang positif mengenai kualitas audit yang dihasilkan, karena auditor bertanggungjawab atas pekerjaannya, melakukan audit dengan upaya yang kuat, menggunakan 
kekuatan pemikiran, mencurahkan seluruh kekuatan pemikiran, serta memobilisasi seluruh energi dan pikiran dalam melakukan audit, sehingga meningkatkan kualitas audit.

\section{c) Pengaruh Objektivitas terhadap}

Kualitas Audit pada Inspektorat

Provinsi Daerah Istimewa

Yogyakarta

Hasil ini mendukung hipotesis 3 yaitu terdapat pengaruh positif Objektivitas terhadap Kualitas Audit pada Inspektorat Provinsi Daerah Istimewa Yogyakarta. Hal ini dibuktikan dengan uji $t$ yang dilakukan menunjukkan bahwa t hitung sebesar 4,112 lebih besar dari t tabel sebesar 2,021 dan nilai probabilitas signifikan 0,004 dan lebih kecil dari 0,050 sehingga dapat disimpulkan bahwa Objektivitas berpengaruh positif terhadap Kualitas Audit pada Inspektorat Provinsi Daerah Istimewa Yogyakarta.

Hasil penelitian ini juga sejalan dengan penelitian yang dilakukan oleh Harvita Yulian Ayuningtyas (2012) tentang Pengaruh Pengalaman Kerja, Independensi, Objektivitas, Integritas, dan Kompetensi terhadap kualitas hasil audit (Studi Kasus pada Auditor Inspektorat Kota/Kabupaten di Jawa Tengah) yang menyatakan bahwa
Objektivitas berpengaruh signifikan terhadap kualitas hasil audit.

Penelitian ini memberikan informasi bahwa Objektivitas berpengaruh positif terhadap Kualitas Audit pada auditor internal di Inspektorat Provinsi Daerah Istimewa Yogyakarta. Hal ini berarti bahwa Objektivitas bisa membuat instansi mempertahankan hal-hal yang positif mengenai kualitas audit yang dihasilkan, karena auditor bertindak secara adil tanpa tekanan atau permintaan yang dipengaruhi oleh pihak yang berkepentingan tertentu pada audit. objektivitas auditor dapat dikembangkan dengan memiliki kemauan untuk melakukan dasar audit, secara umum menerima standar di Indonesia dan situasi nyata, sehingga auditor akan bersikap adil dan tidak subjektif dalam melakukan audit.

d) Pengaruh

Independensi, Akuntabilitas, dan Objektivitas terhadap Kualitas Audit pada Inspektorat Provinsi Daerah Istimewa Yogyakarta

Hasil penelitian ini mendukung hipotesis keempat yaitu adanya pengaruh positif Independensi, Akuntabilitas, dan Objektivitas terhadap Kualitas Audit pada Inspektorat Provinsi Daerah Istimewa Yogyakarta. 


\section{JURNAL NOMINAL / VOLUMEN VIII NOMOR 1 / TAHUN 2019}

Hal ini dibuktikan dengan nilai $F_{\text {hitung }}>F_{\text {tabel }}$ yaitu $12,044>2,850$ dan nilai signifikansi $0,000<0,050$ maka dapat diartikan bahwa Independensi, Akuntabilitas, dan Objektivitas secara simultan berpengaruh positif terhadap Kualitas Audit pada Inspektorat Provinsi Daerah Istimewa Yogyakarta.

Maka dapat disimpulkan bahwa secara bersama-sama Independensi, Akuntabilitas, dan Objektivitas secara simultan berpengaruh positif terhadap Kualitas Audit pada Inspektorat Provinsi Daerah Istimewa Yogyakarta.

Penelitian ini sejalan dengan penelitian yang dilakukan oleh Atta Putra Harjanto (2014) tentang Pengaruh Kompetensi, Independensi, Objektivitas, Akuntabilitas, dan Integritas terhadap Kualitas Audit dengan Etika Auditor sebagai Variabel Moderasi (Studi Empiris KAP di Semarang) menyatakan bahwa secara simultan bersama-sama kompetensi, independensi, objektivitas, akuntabilitas, integritas dan etika auditor berpengaruh positif dan signifikan terhadap Kualitas Audit. Dengan demikian variabel tersebut sangat berpengaruh dalam meningkatkan Kualitas Audit.

Penelitian ini memberikan informasi bahwa Independensi, Akuntabilitas, dan Objektivitas berpengaruh positif terhadap Kualitas Audit. Dengan adanya Independensi maka adanya kejujuran dalam diri auditor dan tidak memihak dalam menyatakan pendapatnya. Selain itu, dengan adanya akuntabilitas auditor maka akan semakin baik pula kualitas auditnya karena auditor bertanggung jawab atas pekerjaannya. Kemudian, Objektivitas juga berpengaruh terhadap Kualitas Audit karena dengan adanya objektivitas auditor maka auditor tidak subjektif dan bertindak secara adil tanpa adanya tekanan dari pihak lain.

\section{SIMPULAN DAN SARAN}

\section{Simpulan}

Independensi berpengaruh positif terhadap Kualitas Audit pada Inspektorat Provinsi Daerah Istimewa Yogyakarta dengan memberikan kontribusi sebesar 33,6\%. Akuntabilitas berpengaruh positif terhadap Kualitas Audit pada Inspektorat Provinsi Daerah Istimewa Yogyakarta dengan memberikan kontribusi sebesar 26\%. Objektivitas berpengaruh positif terhadap Kualitas Audit pada Inspektorat Provinsi Daerah Istimewa Yogyakarta dengan memberikan kontribusi sebesar 33,6\%. Independensi, Akuntabilitas, dan Objektivitas secara simultan berpengaruh positif terhadap Kualitas Audit pada Inspektorat Provinsi Daerah Istimewa 
Yogyakarta dengan memberikan kontribusi $51,5 \%$ sehingga sisanya $48,5 \%$ dipengaruhi oleh variabel lain di luar penelitian ini.

\section{Saran}

Berdasarkan hasil analisis regresi yang diperoleh, diketahui bahwa Independensi, Akuntabilitas, dan Objektivitas memberikan kontribusi sebesar 51,5\%. Diharapkan Inspektorat Daerah Istimewa Yogyakarta dapat meningkatkan Kualitas Auditnya dengan menempuh PPAK dan mengikuti pelatihan, mempertanggungjawabkan pekerjaan dan menyatakan pendapat tanpa adanya pengaruh pihak lain.

Untuk peneliti selanjutnya diharapkan menggunakan indikator variabel yang lebih spesifik untuk membedakan auditor internal atau eksternal. Penelitian ini dengan variabel independen Independensi, Akuntabilitas, dan Objektivitas memberikan kontribusi secara bersama-sama sebesar $51,5 \%$ sehingga $48,5 \%$ dipengaruhi oleh faktor lain di luar penelitian ini. Maka untuk peneliti selanjutnya dapat menambahkan variabel-variabel yang lain yang dapat mempengaruhi Kualitas Audit selain variabel yang diangkat dalam penelitian ini. Diharapkan penelitian selanjutnya dapat menambahkan seluruh Kantor Inspektorat yang ada di Yogyakarta sehingga hasil penelitian dapat lebih luas dan generalisasi.

\section{DAFTAR PUSTAKA}

Ayuningtyas, Harvita Y. (2012). "Pengaruh Pengalaman Kerja, Independensi, Obyektifitas, Integritas, dan Kompetensi terhadap Hasil Audit (Studi Empiris pada AuditorInspektorat Kota/Kabupaten di Jawa Tengah)". Skripsi. Semarang:Universitas Dipenegoro.

Elfarini, Eunike C. 2007. Pengaruh Kompetensi dan Independensi Auditor terhadap Kualitas Audit (Studi Empiris Pada Kantor Akuntan Publik di Jawa Tengah). Skripsi. Universitas Negeri Semarang.

Hafizh, Muhammad. (2017). "Pengaruh Pengalaman Kerja, Akuntabilitas, dan Objektivitas Auditor terhadap Kualitas Audit". Skripsi. Padang: Universitas Negeri Padang

Harjanto, Atta Putra. (2014).’Pengaruh Kompetensi, Independensi, Objektivitas, Akuntabilitas, dan Integritas terhadap Kualitas Audit dengan Etika Auditor sebagai Variabel Moderasi (Studi Empiris KAP di Semarang)". Skripsi. Semarang: Universitas Diponegoro

IIA. (2009). Code of Ethics. The Istitute of Internal Auditors.

Listya Yuniastuti Rahmina, S. A. (2014). Influence of auditor independence, audit tenure, and audit fee on audit quality of members of capital market accountant forum in Indonesia. 324-331.

Mardiasmo. (2005). Akuntansi Sektor Publik. Yogyakarta. Andi Yogyakarta.

Olivia Furiady, R. K. (2015). The Effect of Work Experiences, Competency, 
Motivation, Accountability and Objektivity towards Audit Quality. 2nd Conference on Business and Social Science, 328-335.

Peraturan Menteri Negara Pendayagunaan Aparatur Negara Nomor: PER/05/M.PAN/03/2008 tentang Standar Audit Aparat Pengawasan Intern Pemerintah.

Putri, D. (2015). Pengaruh Kompetensi Auditor, Akuntabilitas, dan Bukti Audit terhadap Kualitas Audit pada KAP di Yogyakarta. Skripsi. Yogyakarta: FE UNY.

Septiana Purwandari. 2013. "Pengaruh Akuntabilitas dan Independensi Terhadap Kualitas Hasil Kerja Auditor (Studi Empiris Pada Kantor Akuntan Publik Surakarta)". Skripsi. Surakarta: Universitas Muhammadiyah Surakarta.

Sugiyono. (2012). Statistika Untuk Penelitian. Cetakan ke-21. Bandung: Alfabeta

Sukriah, Ika. (2009). “Analisis Pengaruh Pengalaman Kerja, Independensi, Obyektifitas,Integritas dan Kompetensi Auditor Terhadap Kualitas Hasil Pemeriksaan”. Tesis. Makassar: Fakultas Ekonomi dan Bisnis, Universitas Hasanuddin.

Yosep, M. (2016). Effect Competencies, Independence, Objectivity of The Function of Internal Audit (Implication for Quality Financial Reporting). Europan Journal Accounting, Auditing, and Finance Reserach, Vol.4, No.5, 57-72. 